THIS huge biography* has many of the virtues and some of the defects of the huge nineteenth-century biographies which Lytton Strachey made fun of while at the same time ransacking them. It begins somewhat pretentiously and ends somewhat tendentiously, and the tone, not to speak of the style, is uneven throughout. There are far too many examples of "was to" and "would be". No Victorian biographer, of course, would have dealt as explicitly or at such length with Russell's sexual adventures as does Ronald Clark, but the treatment of these is not dissimilar from the way a Victorian would have dealt with them had he tried. There is a vast amount of unnecessary detail, and a fair amount of superfluous and repetitive commentary. Yet Clark is doubtless right to refuse to deal with Russell without revealing "the deep emotional complexities" of his personality. Russell himself-at least on one occasion-asked for a biographer who would not treat him as "a solemn stained glass saint existing only for purposes of edification". Like any Bloomsbury character-and such characters dominate many of the middle pages of this volume-he insisted, a little too indulgently, that a biographer would have to recognise above all that "I existed from my own centre."

It was a way of putting things which left a great deal out. It left out, for example, his Whig inheritance which could be identified more specifically than Clark does, and a corresponding set of Whig attitudes which he never entirely shook off. He used popular feelings when he chose to do so, but he never entirely shared them, and he knew instinctively, when he chose to do so, how to appeal to people with power. He was always interested in the relationship between freedom and power, and he never doubted that people should be listening to him on the subject. "I can understand your envying me," he once wrote to Nehru, "because a private person is not obliged to bear in mind the very com-

*The Life of Bertrand Russell. By Ronald W. Clark. Pp. 766. (Jonathan Cape and Weidenfeld and Nicolson: London, 1975.) £6.95.

\section{Portrait of the philosopher}

Asa Briggs

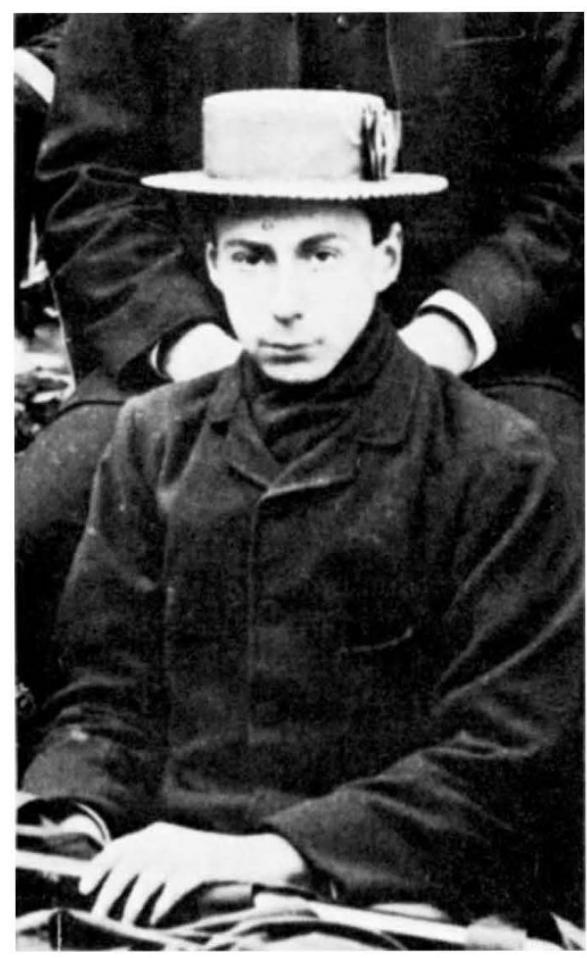

Bertrand Russell as a freshman at Trinty College, Cambridge

plex considerations which beset a head of state."

With Russell's Whiggery went a strong sense of the need for an intellectual aristocracy. "Surely one Darwin is more important than 30 million working men and women." The controversial Ralph Schoenman in a passage of admirable clarity, the kind of clarity which Russell himself often achieved and always appreciated, wrote that there were "serious intellectual doubts which inhibited him from engaging wholeheartedly in mass movements with revolutionary aims. $\mathrm{He}$ felt that cultural excellence and unique achievement were the product of favoured circumstance,"

Russell's own unique achievement is dealt with fairly in this biography. He turned to mathematics as a boy with delight, quickly choosing the most abstract parts" which he understood best. $\mathrm{He}$ needed to detach himself in order to pursue mathematical studies. "I like mathematics," he wrote, "because it is not human and has nothing particular to do with this planet or with the whole accidental universe-because, like Spinoza's God, it won't love us in return." Although he wrote and published German Social Democracy before A Critical Exposition of the Philosophy of Leibniz, he was stimulated and challenged more by Frege than by Bebel. The intellectual collaboration with Whitehead, which culminated in Principia Mathematica, is dealt with fully by Clark: so, too, less fully, is Russell's relationship with Wittgenstein. There is a great deal of relevant unpublished source material in the Bertrand Russell Archives at McMaster University, which Clark has carefully studied, and he has no difficulty in showing in what areas Russell pioneered and on what issues he himself changed his mind. All the references are useful, even when they are not conclusive. There is far more to be written, however, possibly in essays, about Russell's influence on other philosophers and on the study of philosophy itself. Indeed, long though this biography is, the author offers us no final reflections on Russell's position as a mathematician and philosopher.

It may well be that Russell learned more from continental European philosophy than he contributed to it, and that when we seek to establish the intellectual and cultural contours of this century his own thought will be related primarily to the intellectual and cultural history of this country and of the US. When he received the Nobel Prize it was for literature, and his own History of Western Philosophy, a best seller from the moment of its publication, must be judged in very different terms from Principia Mathematica.

Of his eminence-a Victorian concept-there was no doubt. Nor did he himself doubt it. Walking with a friend in Trinity, Cambridge, one day, he pointed to the marble busts on pedestals, waved his hand as he passed the last one, and said, "I shall be here one day." 